\title{
Intizar
}

Vol. 25, No. 1, Juni 2019

Website: http://jurnal.radenfatah.ac.id/index.php/intizar

ISSN 1412-1697, e-ISSN 2477-3816

\section{Materi Parenting Education tentang Pendidikan Seks bagi Remaja dalam Islam Menurut Abdullah Nashih Ulwan}

\author{
Eni Zulaiha $^{{ }^{*} \text {, Nani Nuranisah Djamal }}{ }^{2}$, Tintin Supriyatin ${ }^{3}$ \\ ${ }^{1 *}$ UIN Sunan Gunung Djati Bandung, Indonesia, enzul72@gmail.com \\ ${ }^{2}$ UIN Sunan Gunung Djati Bandung, Indonesia, nani.nuranisah@uinsgd.ac.id \\ ${ }^{3}$ UIN Sunan Gunung Djati Bandung, Indonesia, tintinsupriyatin@ uinsgd.ac.id
}

DOI: https://doi.org/10.19109/intizar.v25i1.3795

\begin{abstract}
Abstrak
Penelitian ini bertujuan untuk mendeskripsikan tentang materi pendidikan seks bagi remaja dalam parenting education menurut Abdullah Nashih Ulwan. Pendekatan dalam penelitian adalah kualitatif dengan metode kepustakaan (library research). Hasil penelitian menunjukan bahwa materi pendidikan seks harus sesuai dengan nilai dan falsafah ajaran Islam. Karena ajaran Islam adalah bermuaranya semua nilai termasuk didalamnya adalah pendidikan seks. Menurut Nashih Ulwan beberapa materi yang harus diajarkan dalam parenting education antara lain: yaitu etika meminta izin, etika melihat, cara menghindarkan dari rangsangan-rangsangan seksual, mengajarkan kepada remaja hukum-hukum syariah yang berhubungan dengan usia remaja dan dewasa, pernikahan dan hubungan seks, isti'faf (menjaga kehormatan diri) bagi yang belum mampu menikah, dan menjelaskan seks kepada remaja secara terang-terangan.
\end{abstract}

Kata Kunci: Parenting Education, Remaja, Pendidikan Seks

\begin{abstract}
This study aims to describe sex education material for adolescents in parenting education according to Abdullah Nashih Ulwan. The research's approach is qualitative with literature reseach as the method. The results of this study show that sex education material must be in accordance with the values and philosophy of Islamic teachings. Because Islamic teachings are the sources of all values including the sex education. According to Nashih Ulwan, the material that must be taught in parent education includes: the ethics of asking permission, ethics of seeing, ways to avoid sexual stimuli, teaching teenagers shariah laws relating to adolescence and adulthood, marriage and sexual relationships, privacy (maintaining self respect) for those who have not been able to marry, and openly explain sex to teenagers.
\end{abstract}

Keywords: Parenting Education, Teenager, Sex Education

\section{Pendahuluan}

Perbincangan mengenai seksualitas bagi sebagian orang masih dianggap sebagai sesuatu yang tabu. Terlebih bila dibicarakan di kalangan remaja. Umumnya mereka tidak sepakat jika seks dibicarakan dalam masyarakat umum. Mereka memandang bahwa seks merupakan urusan rumah tangga, bahkan lebih sempit seks merupakan urusan kamar. Sehingga dikatakan tabu, tidak sopan, jorok, melanggar norma dan etika sosial bagi orang yang membicarakan seks di masyarakat umum (Faucault, 1997). Padahal seksual merupakan bagian integral dalam kehidupan manusia. Tidak hanya berhubungan dengan reproduksi, seksual juga berkaitan dengan masalah kebiasaan atau adat istiadat, agama, seni, moral dan hukum.

Realitas tersebut tidak dapat menghindari keingintahuan para remaja tentang seksual. Bagaimanapun juga persoalan seksual adalah hal alamiah. Relatif banyak kaum remaja yang pada akhirnya memenuhi keingintahuannya tentang seksual melalui media internet yang sering kali tanpa sensor. Hingga budaya vulgar di belahan dunia barat terkadang dipahami dan diadopsi secara apa adanya. Padahal, watak sosiologis suatu kebudayaan tertentu manakala diterapkan, mempunyai implikasi signifikan bagi kehidupan lainnya. Pengetahuan seksual remaja pada umumnya diperoleh dari pergaulan teman sebaya, atau dari bacaan-bacaan 
yang mengungkapkan masalah tersebut. Dari teman sebayanya yang sering memperbincangkan lelucon yang cenderung kotor, sehingga tak jarang akan menimbulkan sesuatu yang bersifat negatif.

Pemahaman remaja tentang seksualitas sering kali kurang memadai itu mengakibatkan lahirnya persepsi keliru (salah). Bahkan memicu lahirnya permasalahan atau kenakalan seksual di kalangan remaja. Berikut ini data penyimpangan seksual remaja dari Komisi Perlindungan Anak Indonesia (KPAI) menyatakan sebanyak 32\% remaja usia 14 hingga 18 tahun di kota- kota besar di Indonesia (Jakarta, Surabaya, dan Bandung) pernah berhubungan seks. Penelitian di tahun 1999 yang dilakukan oleh Sahabat Remaja, sebuah cabang LSM Perkumpulan Keluarga Berencana Indonesia (PKBI), 26\% dari 359 remaja di Yogyakarta mengaku telah melakukan hubungan seks. Menurut PKBI, semua ini pada gilirannya membuka peluang besar bagi remaja melakukan praktik seksual yang tak sehat, perilaku seks pranikah, dengan satu atau berganti pasangan (Fathunaja, 2014).

Sangat disayangkan, bahwa orang sekitar terutamanya orang tua, kurang membantu menunjang pemahaman terhadap masalah seksual remaja. Demikian pula di sekolah, lembaga pendidikan formal juga kurang memberikan pendidikan seksual secara memadai bagi remaja (Meilani, Shaluhiyah, \& Suryoputro, 2014).

Dalam Undang-Undang Nomor 20 Tahun 2003 (Bab I) disebutkan bahwa Sistem Pendidikan Nasional pada dasarnya, pendidikan merupakan tanggung jawab bersama antara keluarga, masyarakat dan pemerintah. Oleh karenanya, pendidikan di Indonesia diselenggarakan melalui tiga jalur pendidikan, yaitu: formal, nonformal, dan informal pada setiap jenjang dan jenis pendidikan. Keluarga merupakan salah satu jalur pendidikan informal selain lingkungan.

Dengan kata lain, keluarga merupakan tempat pendidikan pertama dan utama bagi anak. Keluarga memiliki fungsi dalam pendidikan yaitu mendidik, membimbing, dan membina anggota keluarga untuk memenuhi peranannya sebagai orang dewasa dan makhluk bermasyarakat. Oleh karena itu, keluarga memiliki peran yang sangat mendasar dalam mengoptimalkan semua potensi anak. Peran keluarga tidak dapat tergantikan sekalipun anak telah dididik di lembaga pendidikan formal maupun nonformal (Dini, 2012).

Keterlibatan lembaga pendidikan di luar keluarga memiliki dampak tersendiri dalam proses tumbuh kembang anggota muda keluarga. Selain itu, keselarasan pendidikan yang dilaksanakan di sekolah dan di rumah diakui oleh para ahli pendidikan sebagai salah satu faktor penentu keberhasilan pendidikan anak secara menyeluruh. Hanya saja, kegiatan pembelajaran yang dijalankan oleh lembaga pendidikan seringkali tidak sejalan dengan apa yang telah diterima oleh anak di lingkungan rumah. Orang tua juga kadang tidak bisa sepenuhnya terlibat secara aktif dalam kegiatan pembelajaran yang diikuti oleh anak di luar rumah (lembaga pendidikan). Oleh karena itu, dibutuhkan keikutsertaan para orang tua dalam kegiatan pembelajaran anak baik ketika seorang anak berada di lembaga pendidikan bersama dengan pendidik ataupun ketika anak sudah kembali ke rumah.

Dalam beberapa tahun terakhir, keselarasan pendidikan yang dilaksanakan di sekolah dan di rumah (keluarga) telah menjadi perhatian bersama. Salah satu solusinya adalah melalui parenting education. Parenting adalah cara orang tua bertindak sebagai orang tua terhadap anak-anaknya di mana mereka melakukan serangkaian usaha aktif, karena keluarga merupakan lingkungan kehidupan yang dikenal anak untuk pertama kalinya dan untuk seterusnya anak belajar di dalam kehidupan keluarga (Gunarsa, Gunarsa, \& Singgih, 2012).

Fenomena di lapangan menunjukkan bahwa kegiatan parenting education sangat membantu untuk pembekalan pendidikan orang tua di keluarga. Namun disayangkan materi parenting tentang pendidikan seks bagi bagi kalangan remaja, berdasarkan observasi awal peneliti belum ada standar yang ditawarkan kepada orang tua. Berdasarkan kajian di atas, diperlukan kajian khusus yang mengaji mater-materi parenting education khususnya terkait masalah seks bagi remaja.

Sementara itu, terkait pendidikan seks, Islam memandang bahwa pendidikan seks secara universal. Pergaulan antara laki-laki dan perempuan tidak terbatas pada satu lingkaran. Tetapi dalam segala lingkaran. Pergaulan dikategorikan sebagai

Intizar, Vol. 25, No. 1, Juni 2019 
salah satu unsur rohani yang perlu diberikan, dan hendaknya anak dihindarkan bergaul dengan orangorang yang tidak berakhlak. Sebab pergaulan akan berpengaruh besar terhadap perkembangan jiwa, watak, dan fikiran anak (Dja'far, 1998).

Salah satu tokoh atau sarjana muslim yang telah banyak membahas tentang pendidikan seks bagi remaja adalah Abdulah Nashih Ulwan. Ia dikenal sebagai sarjana yang banyak berkecimpung dalam menyampaikan pemikirannya di dunia pendidikan Islam. Pemikirannya yang begitu tajam dengan analisisnya yang mendalam dari berbagai rujukan terutama sumber hukum Islam, patut untuk dikembangkan sampai sekarang.

Kajian ini melanjutkan penelitian yang sudah ada tentang pentingnya pendidikan seksual bagi remaja di sekolah belum signifikan. Hal ini karena pendidikan seksual masih dianggap hal yang tabu dan hanya persoalan pembelajaran biologis semata (Pakasi \& Kartikawati, 2013). Penelitian ini berbeda dari penelitian di atas, karena penelitian ini menitikberatkan pada peran orang tua dalam mengajarkan pendidikan seksual di rumah, penjelasan materi pendidikan seks bagi remaja melalui parenting education dalam ajaran agama Islam.

\section{Metode Penelitian}

Kajian ini dilakukan dengan pendekatan kualitatif, mengikuti langkah langkah penelitian literatur dan analisis isi pada beberapa literatur yang ditulis Abdullah Nashih Ulwan sebagai sumber primernya.

\section{Hasil Penelitian dan Pembahasan}

\section{Sekilas tentang Abdullah Nashih Ulwan}

Abdullah Nashih Ulwan adalah seorang tokoh muslim. Ia dilahirkan di kota Halab Suriah pada tahun 1928 tepatnya di daerah Qodhi Akar yang terletak di Bandar Halb, Suriah. Dibesarkan dalam keluarga yang berpegang teguh pada agama dan mementingkan akhlak Islam dalam pergaulan dan muamalah sesama manusia. Ayahnya bernama Syekh Said, seorang ulama dan tabib yang disegani.

Ketika Abdullah Nashih Ulwan berumur 15 tahun, dia sudah menghafal Alquran dan sudah menguasai ilmu Bahasa Arab dengan baik (Rohman,
2003). Abdullah Nashih Ulwan sangat cemerlang dalam pelajaran dan selalu menjadi tumpuan rujukan teman-temannya di madrasah. Beliau adalah orang pertama kali memperkenalkan pelajaran Tarbiyah Islamiyah sebagai pelajaran dasar di sekolah. Dan pada perkembangan selanjutnya, pelajaran Tarbiyah Islamiyah ini menjadi mata pelajaran wajib yang harus diambil murid-murid di sekolah menengah di seluruh Suriah. Beliau aktif sebagai dai di sekolahsekolah dan masjid-masjid di daerah Halab.

Abdullah Nashih Ulwan merupakan pemerhati masalah pendidikan terutama pendidikan remaja dan dakwah Islam. Jenjang pendidikan yang dilaluinya yakni setelah menyelesaikan Sekolah Dasar dan Sekolah Lanjutan Tingkat Pertama, melanjutkan Sekolah Lanjutan Tingkat Atas di Halab juga pada tahun 1949. Kemudian melanjutkan pendidikan di alAzhar University (Mesir) mengambil Fakultas Ushuluddin. Selesai pada tahun 1952 selama 4 tahun, dengan meraih gelar sarjana. Ia melanjutkan S-2 di Mesir tahun 1954 dan menerima ijazah spesialis bidang pendidikan setaraf dengan Master Of Arts (MA). Sebelum sempat meraih gelar doktor di Mesir, ia diusir dari Mesir, karena ia seorang aktivis dalam organisasi Ikhwanul Muslimin. Ia juga seorang dai. Tahun 1980 pergi ke tanah Jeddah Arab Saudi setelah mendapatkan tawaran sebagai dosen di Fakultas Pengajaran Islam di Universitas Abdul Aziz.

Abdullah Nashih Ulwan berhasil memperoleh ijazah Doktor di Universitas al-Sand Pakistan pada tahun 1982 dengan disertasi Fikih Dakwah wa Daiyah. Sebagai seorang ulama dan cendikiawan muslim, beliau telah banyak menulis buku, termasuk penulis yang produktif, untuk masalah-masalah dakwah, syariah dan tarbiyah. Spesialisnya ia dikenal sebagai seorang penulis yang selalu memperbanyak fakta-fakta Islami, baik yang terdapat dalam Alquran, Sunah dan atsar-astar para salaf yang saleh terutama dalam bukunya yang berjudul Tarbiyatul Aulad Fil Islam.

Abdullah Nashih Ulwan terkenal dikalangan masyarakatnya sebagai seorang yang berbudi luhur, menjalin hubungan baik antara sesama masyarakat dan selalu menjalankan hikmat masyarakat.

Abdullah Nashih Ulwan meninggal pada tanggal 29 Agustus 1987 M bertepatan dengan 
tanggal 5 Muharram $1408 \mathrm{H}$, pada hari sabtu pukul 09.30 pagi di rumah sakit Universitas Malik Abdul Aziz Jeddah Arab Saudi dalam usia 59 tahun. Jenazahnya dibawa ke Masjidil Haram untuk disolati dan dikebumikan di Makkah (Kholiq, 1999: 53-54).

\section{Arti dan Urgensi Parenting Education}

Secara etimologi kata parenting dalam bahasa Indonesia sepadan dengan pengasuhan. Sedangkan education padanannya dalam bahasa Indonesia adalah pendidikan. Dengan demikian, parenting education dapat diterjemahkan sebagai pendidikan pengasuhan (anak).

Secara istilah, sudah banyak ahli yang mendefinisikan istilah parenting. Brooks (2011) mendefinisikan parenting (pengasuhan) sebagai sebuah proses tindakan dan interaksi antara orang tua dan anak, dimana kedua belah pihak saling mengubah satu sama lain saat anak tumbuh menjadi dewasa. Tindakan itu mencakup merawat, melindungi, dan membimbing kehidupan baru, serta memenuhi kebutuhan anak atas cinta, perhatian dan nilai. Interaksi itu terjadi secara terus menerus antara anak, orang tua, dan masyarakat.

Dari pengertian tersebut, dapat disimpulkan bahwa pengasuhan adalah upaya yang dilakukan orang tua atau orang dewasa dalam menyiapkan anak memiliki kompetensi yang dibutuhkan agar siap hidup di masyarakat dengan baik dan mengikuti norma yang ada.

Orang tua memiliki peranan penting dalam kehidupan anak. Brooks (2011) mengidentifikasi empat peranan orang tua khususnya dalam mempengaruhi perkembangan anak, yaitu (1) memberikan lingkungan yang protektif, (2) memberikan pengalaman yang membawa pada pengembangan potensi maksimal, (3) menjadi penasihat dalam komunitas yang lebih besar, dan (4) menjadi kekuatan yang tak tergantikan dalam kehidupan anak.

Sementara itu, manfaat yang akan diperoleh melalui parenting education antara lain bahwa parenting education bukan hanya untuk menjadi salah satu langkah membesarkan anak dan membangun hubungan, melainkan kemampuan pengasuhan orang tua terhadap anak serta menjadi catatan untuk orang tua ketika menghadapi permasalahan dalam keluarga dengan tujuan untuk mencapai keluarga yang sehat. Selain itu, parenting education yang dilakukan tidak hanya memberikan manfaat bagi keluarga dan pola asuh terhadap anak, melainkan memberikan manfaat bagi orang tua itu sendiri dalam rangka mengubah sikap dan perilaku orang tua yang akan diterapkan pada anak dan keluarga. Perubahan perilaku orang tua disesuaikan dengan bagaimana orang tua memberikan pengasuhan pada anak dengan tuntutan atau tanggapan yang berbeda-beda.

Manfaat lainnya, yaitu memberikan hasil hubungan yang positif antara orang tua dan anak. Orang tua mampu memhami karakter anak, begitupun dengan anak yang menerima perlakuan dari orang tua serta dapat diinternalisasi dalam kehidupannya.

\section{Pendidikan Seks dan Materinya}

Ada beberapa pengertian istilah yang perlu dipahami ketika membicarakan pendidikan seks yaitu: seks, seksualitas, kesehatan seksual dan pendidikan seks itu sendiri. Di kalangan masyarakat awam, keempat istilah ini seringkali tumpang tindih dan dianggap memiliki pengertian yang sama, padahal berbeda. Berikut ini adalah perbedaan pengertian dari keempat istilah tersebut:

Pertama, seks. Seks diartikan sebagai karakteristik biologis umum yang terdapat pada manusia, baik pria maupun wanita. Namun secara kebahasaan seringkali kata ini dimaknai sebagai aktivitas seksual.

Kedua seksualitas. Seksualitas merupakan konsep umum yang mengarah pada seksualitas manusia secara alamiah sebagai bagian dari perkembangan yang dilaluinya pada setiap fase kehidupan, mencakup komponen fisik, psikologis maupun sosial. Seksualitas merupakan aspek penting sebagai manusia sepanjang hidupnya, meliputi jenis kelamin, identitas dan peran jenis kelamin, orientasi seksual, erotisme, kesenangan, keintiman dan reproduksi. Seksualitas dialami dan diekspresikan melalui pikiran, fantasi, keinginan, keyakinan, sikap, nilai-nilai, perilaku, praktik, serta melalui peran dan kegiatan relasional. Meskipun seksualitas mencakup semua dimensi ini, namun tidak semua dapat dialami atau diekspresikan, karena seksualitas sangat Intizar, Vol. 25, No. 1, Juni 2019 
dipengaruhi oleh faktor interaksi biologis, psikologis, sosial, ekonomi, politik, etika, hukum, sejarah, agama dan spiritual (Sarwono, 2012).

Untuk sejumlah alasan, definisi ini sangat berguna. Karena menekankan bahwa seksualitas merupakan pusat keberadaan manusia; tidak terbatas pada kelompok usia tertentu; tidak hanya berhubungan erat dengan gender; melainkan mencakup berbagai orientasi seksual, bahkan jauh lebih luas dari sekedar reproduksi. Hal ini juga membuat jelas bahwa "seksualitas" bukan hanya meliputi elemen perilaku, namun mungkin sangat bervariasi, tergantung pada banyaknya faktor yang mempengaruhi. defi nisi secara tidak langsung menunjukkan bahwa pendidikan seksualitas juga harus ditafsirkan secara lebih luas dan beragam, bukan sekedar "pendidikan terhadap perilaku seksual", hal inilah yang disayangkan dan terkadang dipahami secara keliru.

Ketiga, kesehatan seksual. Merupakan integrasi somatik dari aspek emosional, intelektual dan sosial dari seksualitas manusia. Merupakan cara yang lebih positif untuk meningkatkan kepribadian, komunikasi dan cinta". Meskipun definisi ini agak ketinggalan jaman, namun masih sering digunakan. Selama konsultasi teknis WHO pada tahun 2002, rancangan definisi baru dari kesehatan seksual disepakati. Definisi tersebut berbunyi: Kesehatan seksual adalah keadaan fisik, emosional, mental dan kesejahteraan sosial dalam kaitannya dengan seksualitas; itu bukan hanya tidak adanya penyakit, disfungsi atau kelemahan. Kesehatan seksual membutuhkan pendekatan dan tanggung jawab positif terhadap seksualitas dan hubungan seksual, serta kemungkinan memiliki pengalaman seksual yang menyenangkan dan aman, bebas dari paksaan, diskriminasi dan kekerasan. Untuk kesehatan seksual yang harus dicapai dan dipertahankan, maka hak-hak seksual semua orang harus dihormati, dilindungi dan dipenuhi (Sarwono, 2012).

Keempat, pendidikan seks. Pendidikan seks sebenarnya merupakan bagian dari kajian pendidikan kehidupan berkeluarga yang harus memperoleh dukungan yang kuat dari masyarakat. Pertama kali di perkenalkan dan direkomendasikan oleh State Board Education \& New Jersey pada tahun 1967 poin penting yang menjadi usulannya adalah : 1)
Pendidikan seks sebaiknya menjadi tanggung jawab rumah (keluarga), institusi keagamaan, dan sekolah. 2) Seks merupakan aspek utama (penting) dalam kepribadian, sehingga erat sekali hubungannya dengan aspek emosi dan perkembangan sosial, ia akan memberikan pemahaman yang lebih baik dan lengkap ketika di hubungkan dengan keseluruhan penyesuaian diri individu dalam keluarga maupun masyarakat. 3) Tujuan utama pendidikan seks adalah untuk memperkenalkan secara umum tentang keluarga dan hubungan interpersonal (Dianawati, 2003).

Oleh karena itu menurut Wirda Faswita dan Leny Suarni (2018) pendidikan seksual berkaitan dengan cara pengajaran atau pendidikan yang mampu membantu anak anak remaja menghadapi dan menyelesaikan masalah mereka yang berkaitan dengan dorongan seksual. Sehingga pendidikan seksual ini difokuskan pada penjelasan segala sesuai yang berkaitan dengan dengan seks dan seksualitas dalam bentuk yang wajar.

Materi pendidikan seksual sangat beragam, berbeda-beda satu dengan lain. Menurut Wahyudi (2000) umumnya materi pendidikan seksual adalah sebagai berikut: Pertama, Pubertas. Menurut Hurlock (1990), kata pubertas berasal dari bahasa Latin yang berarti usia kedewasaan. Kata ini menunjuk pada perubahan fisik daripada perubahan perilaku yang terjadi pada saat individu secara seksual menjadi matang dan mampu bereproduksi.

Pada masa kanak-kanak, baik laki-laki maupun perempuan, kelenjar yang mempengaruhi organ seksual (hopotalamus, hipofise) tidak aktif. Pada saat memasuki kematangan seksual, hipotalamus menstimulasi kelenjar hipofise untuk menghasilkan hormon. Selanjutnya, hormon tersebut akan menstimulasi produksi hormon seksual pada ovarium maupun testis. Masa dimana ovarium maupun testis sudah menghasilkan hormon yang dikenal sebagai masa puber (puberty period), masa dimana organ seksual laki-laki dan perempuan mulai berfungsi (Windhu, 2009). Perubahan tanda-tanda seksualitas yang terlihat secara fisik yang terjadi pada remaja terbagi menjadi 3 yaitu primer, sekunder dan tertier. Tanda-tanda seksualitas tersebut harus diketahui oleh remaja, agar ia mengetahui dan 
mempersiapkan psikisnya dengan perubahan fisiknya yang akan atau sedang terjadi.

Kedua. Sistem reproduksi manusia. Sistem reproduksi adalah segala sesuatu yang berhubungan dengan organ-organ tubuh manusia yang memiliki dua fungsi utama yaitu menjalankan berbagai macam aktivitas seksual dan mengandung (hamil) yang menyebabkan kelahiran. Salah satu hal yang dibahas dalam reproduksi manusia adalah memahami anatomi dan fungsi organ reproduksi. Organ reproduksi adalah bagian-bagian tubuh yang berfungsi dalam melanjutkan keturunan.

Ketiga. Kontrasepsi. Remaja juga perlu mengenal dan memahami kontrasepsi, terutama terkait dengan bekal dalam menempuh kehidupan berkeluarga dimasa yang akan datang. Kontrasepsi menggunakan ilmu pengetahuan dan metode pencegahan konsepsi, yaitu mencegah kehamilan. Kontrasepsi juga sebagai kontrol kelahiran.

Keempat. Menstruasi dan mimpi basah. Merurut Windhu (2009), proses menstruasi dimulai dengan proses pematangan sel telur karena rangsangan dari salah satu kelenjar otak yang bernama hipofise. Selama kurang lebih 14 hari sel telur berusaha melepaskan diri dari indung telur tersebut kemudian menuju rahim dan siap untuk dibuahi. Sedangkan mimpi basah pertama terjadi pada remaja laki-laki kira-kira usia 9-14 tahun. Mimpi basah umumnya terjadi secara periodik, berkisar setiap 2-3 minggu. Mimpi basah merupakan pengeluaran cairan sperma secara alami. Ketika testis mulai berreproduksi maka setiap hari testis memproduksi sperma. Remaja yang mengalami mimpi basah merupakan pertanda bahwa organ reproduksinya sudah mulai berfungsi dan telah mencapai pubertas.

Kelima. Penyakit Menular Seksual. Menurut Marmi (2014), penyakit menular seksual (PMS) disebut juga venereal (dari kata venus, yaitu Dewi Cinta dari Romawi Kuno), didefinisikan sebagai salah satu akibat yang ditimbulkan dari aktivitas seksual yang ditimbulkan karena aktivitas seksual yang tidak sehat sehingga menyebabkan munculnya penyakit menular, bahkan pada beberapa kasus PMS justru membahayakan. Menurut Munajat (2000), penyakit menular seksual juga dikenal dengan sebutan STD (Sexually Transmitted Diseasses), yaitu merupakan penyakit yang dapat menular dari seseorang ke orang lain melalui hubungan seksual, PMS juga disebut penyakit kelamin.

\section{Prinsip-Prinsip Materi Pendidikan Seks bagi Remaja Menurut Abdullah Nashih Ulwan}

Menurut Abdullah Nashih Ulwan dalam bukunya Tarbiyatul Aulad Fi al-Islam, pendidikan seks adalah upaya memberikan pengajaran, pengertian, dan keterangan yang jelas tentang masalah-masalah seksual kepada anak. Sehingga ketika anak memasuki usia dewasa/balig dan dapat memahami hal-hal yang berkaitan dengan hidupnya, ia tahu mana yang halal dan yang haram, dan sudah terbiasa dengan akhlak Islam. Ia akan berikap baik. Tidak mengumbar nafsunya. Dan tidak bersikap membolehkan segala hal.

Baberapa kaidah-kaidah terkait materi pendidikan seks menurut pemikiran Abdullah Nashih Ulwan bagi anak, khususnya bagi remaja yang harus diketahui dan diajarkan oleh orang tua kepada anak-anaknya adalah sebagai berikut:

a. Etika meminta izin

Ulwan meletakkan etika meminta izin ke dalam pendidikan seks, dengan mengacu pada Alquran surat an-Nur ayat 58-59. Bahwa seorang anak harus diajarkan dan dibiasakan untuk meminta izin kepada orang tuanya ketika ayah dan ibunya berada dalam situasi yang tidak ingin dilihat oleh siapapun termasuk oleh anakanak remaja. Misalnya minta izin ketika akan memasuki kamar orang tuanya (Ulwan, 2016).

Dalam Alquran surat an-Nur ayat 58-59 Allah memerintahkan kepada orang tua untuk membiasakan (mendidik) remaja-remajanya supaya meminta izin kepada keluarga di dalam tiga waktu, yaitu: 1) sebelum shalat fajar, 2) waktu Zuhur (tidur siang) dan 3) Setelah shalat Isya. Ulwan (2016) menjelaskan bahwa, meminta izin dalam tiga waktu tersebut terdapat nilai-nilai pendidikan untuk remaja mengenai dasar-dasar etika bersama keluarganya. Hikmahnya adalah apabila remaja memasuki kamar orang tuanya atau orang dewasa yang sudah menikah, ia tidak akan dikejutkan oleh sesuatu keadaan yang tidak baik untuk dilihat. b. Etika Melihat 
Dalam menerangkan etika melihat, Ulwan (2016) menjelaskan, bahwa perkara penting lainya yang harus mendapat perhatian dari para pendidik adalah mengajarkan etika melihat lawan jenis kepada remaja saat masih dalam usia kanak-kanak akhir (tamyiz). Hal ini bertujuan agar remaja dapat mengetahui mana yang halal untuk dilihat dan mana yang haram. Dengan begitu, ketika remaja mendekati masa balig dan dewasa, ia telah dibekali dengan akhlak yang istikamah dan mantap.

Terkait etika melihat, Ulwan (2016) menjelaskan secara umum sebagai berikut: Pertama, Etika melihat mahram, Mahram diartikan sebagi setiap perempuan atau laki-laki yang haram untuk dinikahi. Demikian pula setiap laki-laki yang diharamkan bagi perempuan untuk kawin dengannya adalah mahram. Etika yang berlaku bagi mereka hanya boleh melihat pada anggota tubuh yang halal dilihat dan dilarang melihat anggota tubuh yang haram dilihat.

Kedua, Etika melihat tunangan. Ulwan (2016) menjelaskan bahwa syariat Islam membolehkan laki-laki pelamar melihat perempuan yang sedang dipinangnya. Begitupun sebaliknya, hal ini dibolehkan agar masing-masing mengenal dengan jelas dan memutuskan secara pasti saat memilih pasangan hidupnya. Hal ini sebagaimana yang disabdakan Nabi Saw kepada al-Mughirah bin Syu'bah, yang artinya: "lihatlah perempuan itu, karena itu dapat mengekalkan hubungan kalian berdua" (H.R. Al-Tirmidzi).

Keempat. Etika melihat (aurat) istri. Ulwan (2016) menjelaskan bahwa, suami dibolehkan memandang seluruh tubuh istrinya, baik dengan syahwat maupun tidak. Sebab ketika ia boleh menyentuh dan menggauli istrinya maka ia pun boleh melakukan hal yang kurang dari itu, yaitu melihat seluruh tubuhnya, walaupun yang lebih utama adalah masing-masing tidak melihat aurat pasangannya. Dalil yang menerangkan bolehnya melihat seluruh badan adalah yang diriwayatkan oleh Abu Daud, at-Tirmidzi, dan An-Nasa'i, dari Mu'awiyah bin Haydah, ia berkata, "Wahai Rasulullah, dari aurat-aurat kami apa yang boleh terlihat dan yang terlarang?". Beliau menjawab yang artinya: "jagalah auratmu kecuali dari istrimu atau budakmu." (H.R. Abu Daud dan at-Tirmidzi).

Keempat. Etika melihat perempuan lain yang bukan mahram. Laki-laki yang sudah balig tidak dibolehkan melihat perempuan lain yang bukan mahramnya. Lebih lanjut Abdullah Nashih Ulwan menjelaskan bahwa yang dimaksud dengan perempuan yang bukan mahram itu adalah perempuan yang halal bagi laki-laki untuk kawin dengannya, seperti putra dari paman atau bibi (sepupu), saudara ipar (suami kakak atau adik), dan suami bibi. Perempuan yang bukan mahram adalah semua perempuan yang halal bagi laki-laki untuk menikahinya, seperti sepupu dari paman atau bibi, saudari ipar (istri kakak atau adik), istri paman, saudara perempuan istri, dan bibinya. Anak-anak yang sudah memasuki usia remaja atau usia kanak-kanak akhir (tamyiz) disamakan dengan laki-laki dewasa. Mereka harus dipisahkan dengan perempuan yang bukan mahramnya, karena mereka tidak boleh melihat perempuan yang bukan mahramnya.

Kelima. Etika laki-laki melihat sesama laki-laki. Ulwan (2016) menjelaskan dengan tegas bahwa seorang laki-laki tidak dibolehkan melihat laki-laki lain antara pusar sampai lutut, baik laki-laki yang dilihatnya itu kerabat atau muslim maupun nonmuslim. Adapun anggota tubuh lain, seperti perut, punggung, dada, dan lainnya boleh asalkan tanpa syahwat.

Keenam, Etika perempuan melihat sesama perempuan. Sama halnya dengan laki-laki tidak dibolehkan memandang laki-laki lain antara pusar sampai lutut, demikian juga untuk seorang perempuan dilarang memandang bagian tubuh perempuan lainnya, antara pusar sampai lutut, baik perempuan yang dilihatnya itu kerabat atau bukan, muslimah maupun bukan (Ulwan, 2016). Dalilnya adalah sabda Nabi yang artinya: "Laki-laki tidak boleh melihat aurat laki-laki, dan perempuan tidak boleh melihat aurat perempuan".(H.R. Muslim)

Ketujuh. Etika perempuan non muslimah melihat perempuan muslimah. Perempuan 
muslimah diharamkan membuka bagian-bagian tubuhnya yang dapat menimbulkan fitnah di hadapan seorang perempuan kafir, kecuali bagian-bagian tubuh yang biasa tampak pada waktu bertugas, seperti dua tangan, wajah dan dua kaki (Ulwan, 2016).

Kedelapan. Etika melihat anak remaja yang berparas tampan (al-Amrad). Ulwan (2016) menjelaskan, bahwa al-Amrad adalah remaja yang belum tumbuhnya janggutnya, kira-kira umur 10-15 tahun. Ia menjelaskan bahwa memandangnya adalah dibolehkan, jika untuk keperluan jual beli, memberi dan menerima, mengobati, mengajar dan berbagai keperluan lainya. Namun jika memandangnya untuk menikmati keindahanya, maka hukumnya haram. Karena itu akan membangkitkan syahwat dan menimbulkan fitnah.

Kesembilan. Etika perempuan melihat lakilaki yang bukan mahramnya. Ulwan (2016) menjelaskan bahwa seorang muslimah dibolehkan melihat kaum laki-laki yang sedang berpapasan di jalan, atau mempermainkan permainan yang tidak diharamkan, berinteraksi dalam jual beli dan sebagainya. Di samping itu ia memberikan dua syarat perempuan melihat laki-laki lain, yakni: pertama, penglihatan tidak akan menimbulkan fitnah, dan kedua, perempuan melihat laki-laki tidak dalam suatu majelis secara berhadap-hadapan.

Kesepuluh, Etika melihat aurat remaja kecil. Ulwan (2016) juga menjelaskan bahwa, remaja kecil, laki-laki maupun perempuan, yang masih berusia empat tahun tidak mempunyai aurat jika masih berusia empat tahun kebawah. Jika lebih dari empat tahun, maka auratnya adalah kabul, dubur dan sekitarnya. Tapi jika ia telah mencapai batas syahwat, maka auratnya seperti orang balig.

Kesebelas. Keadaan-keadaan terpaksa yang dibolehkan melihat. Ulwan (2016) juga menjelaskan tentang beberapa keadaan yang dibolehkan untuk melihat, walaupun di atas telah dijelaskan secara rinci tentang etika melihat, baik yang dihalalkan maupun yang diharamkan. Adapun keadaan yang dibolehkan untuk melihat yaitu: 1) melihat untuk tujuan melamar/meminang; 2) melihat untuk tujuan mengajar, dengan syarat: ilmu yang diajarkan termasuk ilmu yang bermanfaat untuk kebaikan agama dan dunia, ilmu yang diajarkan adalah diperuntukkan bagi perempuan, melihatnya tidak dikhawatirkan menjadi fitnah, tidak berduaan ketika mengajar, dan tidak ada perempuan yang mengajarkan ilmu tersebut; 3 ) melihat untuk tujuan pengobatan; dan 4) melihat untuk tujuan peradilan dan meminta persaksian

Seperti halnya etika meminta izin, Ulwan telah memberikan pedoman dalam pendidikan seks untuk remaja dari persoalan akhlak dan etika. Dasar yang digunakan tidak bersinggungan dengan pendidikan seks, Beliau lebih condong pada persoalan akhlak. Hal ini sebuah konsekuensi bahwa, kerangka pendidikan seks lebih diarahkan pada persolan etika atau pembentukan akhlak terpuji.

c. Menghindarkan anak dari rangsangan seksual

Menjaga anak, terutama yang berada pada masa peralihan (pubertas/balig) agar tidak terkontaminasi oleh stimulus yang dapat memancing munculnya dorongan seksual mereka. Dengan menghindarkan remaja dari rangsangan seksual, agar remaja tidak terjerat dari tali kekejian, jauh dari lembah kehinaan dan bergelimang di lumpur kerusakan dan penyimpangan (Ulwan, 2016).

Untuk menjaga agar terhindar dari bahaya rangsangan seksual, Nashih Ulwan menegaskan pentingnya pengawasan terhadap faktor internal dan eksternal. Pengawasan faktor internal dapat dilakukan dengan cara: mengajarkan etika minta izin dalam 3 waktu (sebelum Shubuh, Zuhur dan setelah Isya); membiasakan untuk tidak memasuki tempat-tempat yang banyak lawan jenisnya; tidak tidur bersama saudara laki-laki maupun perempuan dalam satu tempat tidur; menjaga pandangan mata; menghindari tontonan yang berbau pornografi atau dapat merangsang dorongan seksual.

Sementara itu, pengawasan faktor eksternal, jauh lebih berat karena banyak saluran yang dapat menjadi jalan masuknya pengaruh negatif bagi anak. Diantaranya

Intizar, Vol. 25, No. 1, Juni 2019 
melalui adegan dalam film-film bioskop yang dapat merangsang dorongan seksual; mode pakaian wanita yang mempertontonkan aurat; sarana prostitusi atau tempat-tempat umum yang biasa digunakan untuk berkumpul antara laki-laki dan perempuan (seperti tempat biliar, karaoke, atau tempat-tempat hiburan sejenisnya termasuk tempat rekreasi, cafe); iklan-iklan di tempat umum yang mempertontonkan aurat wanita; pergaulan yang negatif (seperti gang motor, atau gang lainya); pergaulan bebas antara laki-laki dan perempuan

d. Mengajarkan anak kajian hukum (Fikih) yang terkait perkembangan anak usia remaja

Mengajarkan hukum agama tentang kecenderungan meningkatnya dorongan seksual dan kematangan seksual, seyogyanya dimulai sejak usia pra pubertas. Jika anak sudah memasuki usia pubertas (sekitar 12-15 tahun) dan mengalami menarke pada anak perempuan atau mimpi basah (wet dream) pada anak lakilaki, maka orang tua harus menjelaskan tentang konsep balig dan mukalaf (kewajiban untuk menjalankan syariat Islam dan menjauhi larangan-larangan agama karena usianya yang sudah balig).

Dorongan seksual yang meningkat pada usia pubertas ini memiliki implikasi terhadap kewajiban agama dan beban syariat. Pihak pertama yang paling bertanggung jawab dalam hal ini adalah orang tua, baru kemudian guru atau pembimbing dalam pendidikan.

Nashih Ulwan (2016) menyebutkan sedikitnya ada tujuh hukum yang perlu diajarkan pada anak saat mereka memasuki usia balig. Ketujuh hukum tersebut adalah: Pertama, apabila anak laki-laki maupun perempuan mimpi bersetubuh, dan ketika bangun kainnya tidak basah, maka tidak berkewajiban untuk mandi; Kedua, apabila anak laki-laki maupun perempuan tidak mimpi bersetubuh, namun ketika bangun kainnya basah (bukan kencing biasa), maka mereka berkewajiban untuk mandi. Ketiga, keluarnya mani dari laki-laki atau perempuan dengan memancar dan bersyahwat, sebagaimana kebiasaannya telah menyebabkannya mandi wajib. Keempat, memasukan kepala zakar (hasyafah atau batang penis, yaitu bagian yang dikhitan) ke dalam kemaluan atau dubur, telah menyebabkan pelaku dan pasangannya untuk mandi, baik telah mengeluarkan mani maupun belum; Kelima, berhentinya masa haid dan nifas telah mewajibkan mandi bagi perempuan; Keenam, adalah wajar apabila jika setelah remaja mempelajari hal- hal yang mewajibkan mandi, ia pun mempelajari masalah kefarduan, sunah dan tata cara dalam mandi tersebut; Ketujuh, penting juga remaja diberi pengetahuan tentang hal-hal yang haram dikerjakan selama dalam keadaan junub, agar tidak jatuh ke dalam perbuatan haram.

e. Memberikan informasi seputar perkawinan dan hubungan seksual

Manusia diciptakan Allah dengan kecenderungan dan naluri untuk mememelihara kelestarian jenisnya. Untuk kepentingan inilah Allah menetapkan hukum-hukum guna memenuhi tuntutan kecenderungan dan naluri tersebut. Perkawinan merupakan hukum yang ditetapkan ajaran Islam sebagai pemenuhan naluri atau kecenderungan kepada lawan jenis, agar manusia dapat menjalani fitrah seksual dengan penuh keharmonisan dan kesesuaian, tanpa fitnah atau akibat-akibat yang yang merugikan. Ada dua hal yang penting untuk dipahami dalam hal ini adalah: pandangan Islam tentang naluri seksual dan, hikmah dari perkawinan.

Di samping itu, dipaparkan bahwa dengan adanya pernikahan, maka terdapat beberapa hikmah, diantaranya: memelihara garis keturunan, selamatnya masyarakat dari bahaya penyimpangan moral, adanya kerjasama antara suami istri di dalam tanggung jawab keluarga, selamatnya masyarakat dari penyakit fisik dan gangguan kejiwaan, mendatangkan ketentraman jiwa, dan menghasilkan generasi Muslim yang saleh (Ulwan, 2016).

f. Isti'faf (menjaga kehormatan diri) bagi yang belum mampu menikah

Pada dasarnya menjaga kehormatan diri bukanlah pengekangan. Sebab pengekangan, 
akan menodai terhadap naluri seksual. Tetapi Islam juga tidak memperbolehkan seseorang untuk memenuhi tuntutan biologisnya hanya karena tuntutan nafsu saja. Islam telah meletakkan batas-batas syariat yang memperbolehkan memenuhi tuntutan itu (Ulwan, 2016).

Dengan kata lain, menurut Ulwan bahwa menanamkan isti'faf merupakan hal yang tidak boleh dilupakan bagi yang belum mampu menikah. Hal ini karena sangat urgen, mereka yang telah menjaga kehormatan dirinya berarti menjaga dirinya terjerumus ke dalam penyimpangan dan penyesalan tanpa henti.

g. Menjelaskan masalah seksual secara terbuka

Mayoritas orang tua merasa riskan ketika harus menjelaskan tentang seksualitas kepada anak mereka. Padahal dalam ajaran Islam banyak dalil yang menunjukkan bahwa orang tua atau guru dibolehkan untuk memberikan penjelasan kepada putra putrinya atau muridnya tentang seks. Bahkan terkadang menjelaskan itu menjadi wajib jika berkaitan dengan akibat syariat yang ditimbulkan dari suatu perbuatan tertentu.

Menjelaskan tentang masalah seksualitas kepada anak, erat kaitannya dengan pendidikan etika da tata karma. Terutama tata krama dalam menyalurkan dorongan biologis yang meningkat pada usia balig, agar tidak disalahgunakan. Tata krama ini juga akan terus berlanjut hingga memasuki pintu pernikahan. Semua penjelasan ini dimaksudkan agar generasi muda tidak terjerat perbuatan dosa yang disebabkan oleh doronga seksual pada diriya.

Dalam memberikan keterangan masalah seks kepada remaja, Ulwan (2016) mengingatkan untuk memberikan pengajaran yang sesuai pada setiap fasenya serta seorang ibu memberikan keterangan masalah seks kepada putrinya (remaja perempuan), seorang ayah memberikan keterangan seksual kepada putranya (remaja laki-laki). Lebih lanjut, Ulwan menekankan dan seyogyanya dilakukan oleh orang tua adalah memberi perhatian dan pengawasan serta memanfaatkan kesenggangan waktu luang.

\section{Analisis Pemikiran Nashih Ulwan tentang Pendidikan Seks Sebagai Materi dalam Parenting Educatioan}

Pemikiran Ulwan dalam konteks pendidikan seks pada dasarkan tidak dikhusukan bagi remaja tapi berdasarkan tahapan-tahan usian anak. Namun pendidikan seks bagi remaja memiliki perhatian khusus. Prinsip-prinsip pendidikan seks tersebut jika diterapkan dan dijadikan sebagai materi dalam parenting education sesungguhnya dilandasi oleh pemikiran akan pentingnya fungsi dan peran keluarga dalam pendidikan anak dan pentingya keterhubungan keluarga dengan lembaga pendidikan. Hal itu, sebagaimana pendapat Ki Hajar Dewantara, bahwa tripusat pendidikan yang pertama dan terpenting yang memiliki tugas mendidik budi pekerti dan laku sosial anak. Alam keluarga ini menurutnya harus berhubungan dengan baik dengan alam perguruan (lembaga pendidikan) yang bertugas mengusahakan kecerdasan pikiran dan memberi ilmu pengetahuan, dan alam pemuda yang bertugas membantu mencerdasan jiwa dan budi pekerti anak (Soeratman, 1985).

Peranan mendasar orang tua terhadap anak dalam konsepsi Islam dijelaskan dalam Hadis Nabi yang berbunyi, "Anak dilahirkan dalam kondisi suci (baik), kemudian ibu bapaknya lah yang menjadikannya Yahudi, Nasrani, atau Majusi” (H. R. Muslim). Orang tua berdasarkan Hadis ini berperan mengarahkan anaknya dengan kecelakaan dan kritikan pedas serta hukuman fisik yang berbahaya, (5) pendidikan intelektual dan moral, (6) persiapan untuk bertanggungjawab sebagai orang dewasa, dan (7) mempertanggungjawabkan tindakan anak kepada masyarakat luas.

Dengan demikian, perbedaan mendasar tentang tawaran konsep atau materi pendidikan seks dari Ulwan jika dibandingkan dengan pendidikan seks yang selama ini diajarkan secara umum sebagaimana telah dikemukan di atas, bahwa pendidikan seks dalam Islam merupakan perlakuan proses sadar dan merupakan bagian dari etika untuk menyampaikan proses perkelaminan menurut nilai-nilai dan prinsipprinsip Islam. Pendidikan seks dalam Islam bukanlah 
pendidikan tentang how to do (bagaimana melakukan hubungan seks), atau hubungan seks aman, tidak hamil dan lain sebagainya, tetapi pendidikan seks merupakan sebuah upaya meningkatkan kerangka moralitas yang didasarkan pada ajaran agama Islam. Pendidikan seks tidak boleh bertentangan dengan ajaran Islam. Ketika seks terlepas dari kerangka moral Islam, maka kerusakan moral kaum terpelajar justru akan semakin mewabah.

Pandangan sebagian masyarakat bahwa anakanak tidak perlu diberikan pendidikan dan pembelajaan mengenai seks, karena beranggapan bahwa anak-anak setelah mereka remaja mereka akan tahu dengan sendirinya adalah keliru. Begitu pula orang tua yang merasa riskan untuk membicarakan dan menyampaikan masalah seks kepada anak-anaknya adalah tidak tepat. Terlebih jika berpendapat, bahwa pengetahuan seks akan menambah jumlah penyimpangan seksual.

Prinsip-prinsip pembelajaran seks menurut Ulwan yang didasarkan pada prinsip-prinsip ajaran Islam merupakan bekal atau pengetahuan yang sangat berharga bagi orang tua, khususnya yang mengikuti parenting education. Namun demikian, tentunya para pendidik atau orang tua hendaknya memberikan kaidah ini dengan penjelasan secara proporsional, dalam arti tidak terlalu eksklusif sehingga menjadikan gerak atau tingkah laku remaja semakin terkekang.

Memang jika kita berbicara mengenai pendidikan seks, tak akan lepas dari sikap pro dan kontra. Ada sebagian orang yang menyetujui disosialisasikannya pendidikan seks, ada sebagian anggota masyarakat yang menolaknya. Dengan dasar itu, meskipun sependapat dan mendukung solusi yang ditawarkan Ulwan, namun kenyataan membuktikan adanya anggapan yang cukup hampir mendarah daging bahwa mensosialisasikan pendidikan seks adalah tabu. Di sini artinya mensosialisasikan pendidikan seks tidak sesederhana apa yang ada dalam benak masing-masing orang. Bagi mereka yang menolak, mereka menganggap seks adalah kotor, cabul dan porno. Karena itu menurut mereka, seks tidak perlu diajarkan (Miqdad, 2001).

Intizar, Vol. 25, No. 1, Juni 2019
Tumbuhnya persepsi semacam itu, antara lain disebabkan merembesnya paham-paham ajaran Gereja Masehi pada abad pertengahan di Eropa ke dalam benak umat Islam (Ayib, 1991). Di samping itu, juga karena pendapat mereka sedikit banyak mendapat dorongan secara nyata dengan meluasnya dekadensi moral dan gejala yang tidak sehat dalam masyarakat, seperti kebejatan moral di kalangan remaja, pemerkosaan, free sex dan lain sebagainya. Betapapun banyak orang beranggapan bahwa masalah seks amatlah tabu untuk dibicarakan, namun kenyataan sehari-hari, manusia tidak lepas dari kebutuhan seks. Seks adalah kebutuhan asasi yang tidak dapat dipisahkan dari kehidupan manusia. "kebutuhan seksual pada diri manusia merupakan kebutuhan dasar" (Ayib, 1991).

Sejalan dengan itu, pendidikan seks dalam kerangka Ulwan merupakan sebuah langkah yang dilakukan oleh pendidik (orang tua) untuk memberikan bekal kepada remaja dalam rangka membentengi diri remaja agar tidak diperbudak oleh hawa nafsu. Oleh karenanya, konsep pendidikan seks Ulwan yang ditawarkan mencakup berbagai aspek. Di samping itu juga materi yang ditawarkan pun bersifat komprehensif serta holistik.

\section{Kesimpulan}

Pendidikan seks menurut Abdullah Nashih Ulwan adalah upaya memberikan pengajaran, pengertian, dan keterangan yang jelas tentang masalah-masalah seksual kepada anak, ketika ia sudah memahami hal-hal yang berkaitan dengan seks dan pernikahan. Pemikiran Ulwan tentang pendidikan seks meliputi tujuh aspek, yaitu etika meminta izin, etika melihat, cara menghindarkan dari rangsangan-rangsangan seksual, mengajarkan kepada remaja hukum-hukum syariat yang berhubungan dengan usia remaja dan dewasa, pernikahan dan hubungan seks, isti'faf (menjaga kehormatan diri) bagi yang belum mampu menikah, dan menjelaskan seks kepada remaja secara terangterangan.

Pendidikan seks dalam kerangka Ulwan ini merupakan sebuah kerangka dasar yang dapat disampaikan sebagai pembelajaran kepada orang tua, khususnya yang mengikuti program parenting education. Dengan demikian, para orang memiliki 
bekal dan pengetahui memadai dalam mengasuh dan mendidik anak-anak mereka, khususnya yang sudah menginjak remaja, dalam rangka membentengi diri remaja agar tidak diperbudak oleh hawa nafsu.

\section{Daftar Pustaka}

Ayib, S. (1991). Islam dan Pendidikan Seks Remaja. Solo: Pustaka Mantiq.

Dianawati, A. (2003). Pendidikan seks untuk remaja. Jakarta: Kawan Pustaka.

Dini, D. P. P. A. U. (2012). Pedoman Penyelenggaraan Pendidikan Anak Usia Dini Berbasis Keluarga. Jakarta: Dirjen PAUD, Nonformal, dan Informal.

Dja'far, M. (1998). Beberapa Aspek Pendidikan Islam. Surabaya: Al-Ikhlas.

Faswita, W., \& Suarni, L. (2018). Hubungan Pendidikan Seks dengan Perilaku Seksual pada Remaja Putri di SMA Negeri 4 Binjai Tahun 2017. JUMANTIK (Jurnal Ilmiah Penelitian Kesehatan), 3(2), 28-45.

Fathunaja, A. (2014). Reorientasi Pendidikan Seks Terhadap Anak Usia Remaja di Sekolah (Memadukan Sains dan Agama dalam Pembelajaran). Jurnal Pendidikan Sekolah Dasar Ahmad Dahlan, 1(1), 104-124.

Faucault, M. (1997). Histoire De La Seksualite 1: La Volante De Savior. Jakarta: Gramedia Pustaka Utama.

Gunarsa, S., Gunarsa, \& Singgih, Y. (2012). Psikologi untuk Muda Mudi. Jakarta: Libri.

Hurlock, E. B., Istiwidayanti, Sijabat, R. M., \& Soedjarwo. (1990). Psikologi perkembangan: Suatu pendekatan sepanjang rentang kehidupan. Jakarta: Erlangga.

Jane, B. (2011). The Process of Parenting. Yogyakarta: Pustaka Belajar.

Marmi. (2014). Kesehatan Reproduksi. Yogyakarta: Pustaka Pelajar.

Meilani, N., Shaluhiyah, Z., \& Suryoputro, A. (2014). Perilaku ibu dalam memberikan pendidikan seksualitas pada remaja awal. Kesmas: National Public Health Journal, 8(8), 411-417.

Miqdad, A. A. A. (2001). Pendidikan Seks Bagi Remaja. Yogyakarta: Mitra Pustaka.

Munajat, N. (2000). Modul; Resiko Reproduksi
Remaja. Bandung: PKBI.

Pakasi, D. T., \& Kartikawati, R. (2013). Antara kebutuhan dan tabu: pendidikan seksualitas dan kesehatan reproduksi bagi remaja di SMA. Jurnal Makara Seri Kesehatan, 17(2), 79-87.

Rohman, M. (2003). Abdullah Nasih Ulwan: Pendidikan Nilai. Yogyakarta: Jendela.

S, R. W. (2000). Modul; Kesehatan Reproduksi Remaja. Bandung: PKBI.

Sarwono, S. W. (2012). Psikologi Remaja. In Raja Grafindo Persada. Jakarta: Raja Grafindo Persada.

Soeratman, D. (1985). Ki Hajar Dewantara. Jakarta: Proyek PSPB Dikbud.

Ulwan, A. N. (2016). Pendidikan Anak Dalam Islam. Solo: Insan Kamil.

Windhu, S. C. (2009). Disfungsi Seksual; Tinjauan Fisiologis dan Patologis terhadap Seksualitas. Yogyakarta: Andi Offset. 